DOI: $10.31393 /$ reports-vnmedical-2021-25(3)-26

UDC: $616.521-07: 616-071.2+159.922$

\title{
LEADING TYPOLOGICAL CHARACTERISTICS OF TEMPERAMENT AND PSYCHODYNAMIC FEATURES OF PERSONALITY IN MEN WITH VARIOUS FORMS OF ECZEMA
}

Al-Omary Ala'a Osama Ahmad', Stepanenko R. L.' ${ }^{2}$, Mateshuk-Vatseba L. R. ${ }^{3}$, Kizina I. E. ', Rekun T. O.'

${ }^{1}$ National Pirogov Memorial Medical University, Vinnytsya (Pyrogov street 56, Vinnytsya, Ukraine, 21018),

${ }^{2}$ Bogomolets National Medical University, Kyiv (T. Shevchenko blvd. 13, Kyiv, Ukraine, 01601),

${ }^{3}$ Danylo Halytsky Lviv National Medical University, Lviv (Pekarska street 69, Lviv, Ukraine, 79010)

Responsible for correspondence: e-mail: alaaalomari33@yahoo.com

Received: July, 05, 2021; Accepted: August, 05, 2021

Annotation. The problem of causation in the formation of eczema in terms of psychosomatic relationship is currently relevant and virtually unresolved. The application of the complex principle of research determines a multifaceted assessment of the psychological state of the personality of patients with eczema and the possibility of its optimal correction. The aim of the study was to study the differences between the indicators of the leading typological characteristics of temperament and psychodynamic features of personality between healthy and/or eczema patients depending on the severity of dermatosis. Men aged 22 to 35 years, with a diagnosis of true and microbial eczema, were evaluated for the leading typological characteristics of temperament according to the Eysenck questionnaire and psychodynamic personality traits according to the Spielberger-Khanin questionnaire. As a control from the data bank of the research center of National Pirogov Memorial Medical University, Vinnytsya indicators of the level of subjective control of 82 practically healthy men of the same age group were selected. Statistical processing of the results was performed in the license package "Statistica 5.5" using non-parametric evaluation methods. In general, it was found that among patients with eczema $5.6 \%$ are introverts, potential introverts - $12.3 \%$, ambiverts - $44.6 \%$, potential extroverts $-29.0 \%$ and extroverts - $8.5 \%$. Compared with healthy individuals, the percentage of patients with various forms and severity of eczema is higher due to subjects with low (all groups of patients) and potentially low levels of neuroticism (true eczema of mild course), low situational (true eczema of mild course eczema and microbial eczema of severe course) and personal (truth of severe eczema) anxiety, and lover - due to patients with potentially high levels of neuroticism (truth of severe eczema), moderate (severe microbial eczema) and high (truth of eczema mild) level and situation level of personal anxiety (the truth of mild eczema). Patients with severe disease are characterized by a higher level of neuroticism (true eczema) and a higher level of personal anxiety (microbial eczema) compared to patients with mild disease. Patients with severe microbial eczema have a higher level of situational anxiety compared to patients with true eczema of similar severity. Thus, psychodiagnostics, which is based solely on patients' self-description of their behavior, emotional and volitional state, leads to inconsistency, subjectivity, uninformativeness of the results of the study and does not reveal the dynamics of the disease or treatment features.

Keywords: eczema, psychological tests, anxiety, extraversion, introversion, neuroticism.

\section{Introduction}

Currently, it is generally accepted that the important role of emotional stress in the pathogenesis of eczema. Both exogenous stress and the disease itself, as its manifestation, are of sufficient importance. In $19-63 \%$ of cases, the manifestation and exacerbation of eczema are caused by various psycho-emotional factors. In addition to the relationship between the duration of psycho-emotional stress and manifestations of skin pathology, there is often a pronounced parallelism between the severity of the disease, activity, prevalence, and intensity of psychoemotional disorders $[6,7,15]$.

At the end of the XVIII century V. Falconer (1788) was the first to publish data relating to psychodermatology, which substantiated the relationship between the activity of dermatoses and the violation of the conduction of nerve impulses to the affected areas of the skin. In general, in the works of that time in the reproduction of the pathophysiological mechanisms of eczema a leading role was played by negative psycho-emotional factors, which served as the basis for the selection of psychosomatosis.
A. G. Poltebnov (1972) came to the conclusion that the basis of the pathogenesis of chronic dermatoses are functional disorders of the nervous system [18]. O. V. Pavlova (2007) considers the etiopathogenesis of chronic dermatoses in the framework of the theory of P. K. Anokhin functional systems and transfers the physiological mechanisms of perseveration and retention to the processes that explain and characterize the beginning of the development of psychosomatic disorders [16].

Later, many clinicians began to view the skin as a highly sensitive organ to stress, mainly due to a combination of genetic, constitutional, and individual predispositions. Psychotraumatic factors, in their opinion, can act only as a link in the sequence of immunological changes and lead to recurrence of dermatosis in conjunction with the main factors of pathogenesis [5]. The problem of the relationship of mental, somatic and organ components is studied and studied over a long period of time. However, the structure of the pre-disease of patients suffering from eczema needs special consideration and clinical clarification. 
The aim of the study was to study the differences between the indicators of the leading typological characteristics of temperament and psychodynamic features of personality between healthy and/or eczema patients depending on the severity of dermatosis.

\section{Materials and methods}

To achieve this goal, men aged 22 to 35 years, with a diagnosis of true $(n=34$, including 16 with mild and 18 with severe) and microbial $(n=38$, including 28 with mild and 10 with severe) eczema get assessment of the leading typological characteristics of temperament according to the questionnaire of $\mathrm{H}$. Eysenck [11] [AZ_E - indicator on the scale of extraversion-introversion on Eysenck (score); AZ_N - indicator on the scale of neuroticism on Eysenck (score); $A Z$ L - indicator on scale of insincerity according to Eysenck (score) and psychodynamic personality traits according to the Spielberger-Hanin questionnaire [11] (SP_ST - indicator of situational (reactive) anxiety according to Spielberger (score); SP_LT - indicator of personal anxiety according to Spielberger (score)).

As a control from the database of the research center of the National Pirogov Memorial Medical University, Vinnytsya were selected indicators of the leading typological characteristics of temperament and psychodynamic personality traits of 82 practically healthy men of the same age group.

Statistical processing of the results was performed in the license package "Statistica 5.5" using non-parametric evaluation methods. The reliability of the difference between the values between the independent quantitative values was determined using the Mann-Whitney U-test.

\section{Results. Discussion}

The prevalence of eczema among patients with chronic dermatoses is constantly increasing. This is due to the growing importance of traumatic factors as one of the reasons for the development of this pathology. Patients with eczema are characterized by increased irritability, anxiety, severe asthenia, phobias and hypochondriac manifestations. In many cases, there are prolonged depressive disorders [13].

The problem of causation in the formation of eczema in terms of psychosomatic relationship is currently relevant and virtually unresolved. The application of the complex principle of the study leads to a multifaceted assessment of the psychological state of the personality of patients with eczema and the possibility of its optimal correction [19].

In the course of psychological research in patients with different forms and severity of eczema, no significant differences were found on the scale of extraversion introversion. Only in patients with mild microbial eczema, the indicator on this scale $(14.68 \pm 3.04$ points) tends $(p=0.082)$ to higher values compared with those with severe microbial eczema (12.80 \pm 3.29 points).

The high level of the indicator on the scale of extraversion
- introversion, determined in isolated cases in some subjects, did not affect the average values, which amounted to $13.88 \pm 4.62$ and $13.11 \pm 3.05$ points (true eczema of mild and severe course), $14.68 \pm 3.04$ and $12.80 \pm 3.29$ points (The truth of eczema is mild and severe). In the vast majority of patients with eczema and in the studied control groups, the values of the extraversion-introversion index were within ambiversion.

In addition to the average values of the severity of the extroversion index, the percentage distribution of patients by its value was determined. Thus, the percentage of patients with true mild eczema with introversion tends to be higher $(p=0.062)$ compared with patients with microbial eczema $(12.50 \%$ and $0 \%$, respectively). The percentage of patients with mild microbial eczema with ambiversion was significantly $(p<0.05)$ higher than patients with severe microbial eczema ( $12.50 \%$ and $0 \%$, respectively). The percentage of healthy patients with potential extraversion was significantly $(p<0.05)$ higher than patients with severe microbial eczema (42.68 \% and $0 \%$, respectively).

The percentage of patients with true severe eczema and mild microbial eczema with potential extraversion was significantly $(p<0.05)$ higher than patients with severe microbial eczema (38.89\%, $46.40 \%$ and $0 \%$, respectively).

Analyzing the above, we can conclude that the severity, form of eczema and the level of extroversion are not interdependent. The level of extroversion is an individual norm of human reaction and is determined not by a certain nosological unit, but by a person who is as individual and dynamic as the inner world of each individual.

The results of assessing the level of neuroticism in different groups of patients as a basic indicator of psychoemotional instability deserve special attention. It was found that all subjects, including the control group, have a potentially low level of the indicator. Unexpectedly, the indicator on the scale of neuroticism was significantly $(p<0.05)$ lower in patients with true eczema of mild course $(7.063 \pm 3.732$ points $)$ and tends $(p=0.054)$ to lower values in patients with microbial eczema of mild course (8.143 \pm 4.712 points) compared with practically healthy subjects (10.29 \pm 5.52 points).

The percentage of people with low levels of neuroticism (concordant) is significantly $(p<0.05-0.001)$ higher in patients with true eczema of mild course, microbial eczema of mild and severe course and tends $(p=0.066)$ to higher values in patients with true eczema of severe course compared with the control group $(62.50 \%, 42.86 \%, 40.00$ $\%, 27.78 \%$ and $10.98 \%$, respectively).

The percentage of individuals with potentially low levels of neuroticism (potential concordant) was significantly $(p<0.05)$ lower in patients with true mild eczema compared to healthy subjects $(6.25 \%$ and $34.15 \%$, respectively).

The percentage of persons with a potentially high level of neuroticism (potential discordant) tends $(p=0.073)$ to lower values in patients with true severe eczema compared with the control group ( $0 \%$ and $15.85 \%$, respectively). 
The indicator of situational (reactive) anxiety according to Spielberger is significantly $(p<0.05)$ lower in patients with true eczema of severe course (36.67 \pm 6.26 points) and tends $(p=0.051)$ to lower values in patients with true eczema of mild course (35.60 \pm 5.03 points) compared with practically healthy subjects $(40.09 \pm 7.46$ points).

The percentage of people with a low level of situational anxiety is significantly $(p<0.01)$ higher in patients with severe microbial eczema and tends $(p=0.052)$ to higher values in patients with true mild eczema compared with the control group (respectively $30.00 \%, 18.75 \%$ and $4.88 \%$ ). The percentage of people with a moderate level of situational anxiety was significantly $(p<0.05)$ lower in patients with severe microbial eczema compared with the control group (40.00\% and $73.17 \%$, respectively). The percentage of persons with a high level of situational anxiety was significantly $(p<0.05)$ lower in patients with true mild eczema compared with the control group (0\% and $20.73 \%$, respectively).

The Spielberger personal anxiety index was significantly $(p<0.01)$ lower in patients with severe eczema $(33.33 \pm 4.59$ points) compared with practically healthy persons (38.47 \pm 7.21 points).

The percentage of people with a low level of personal anxiety tends $(p=0.064)$ to higher values in patients with true severe eczema compared with the control group (33.30 $\%$ and $14.63 \%$, respectively). The percentage of people with a high level of personal anxiety tends $(p=0.052)$ to lower values in patients with true severe eczema compared to the control group ( $0 \%$ and $18.29 \%$, respectively).

In terms of sincerity, a significant difference was found between the main and control groups. Healthy subjects, in contrast to patients, were more candid, their average results did not exceed the "norm". Thus, the Eysenck insincerity index was significantly higher $(p<0.001)$ in patients with true eczema of mild (5.500 \pm 1.506 points) and severe (5.556 \pm 2.064 points) course and in patients with microbial eczema of the mild (5.321 \pm 1.467 points) and severe $(5.900 \pm 1.853$ points) course in comparison with practically healthy subjects $(3.329 \pm 1.078$ points).

The percentage of people with an insincerity score of up to 3 points (normal) in patients with true eczema of mild course tends $(p=0.075)$ to lower values compared to healthy subjects (respectively $12.50 \%$ and $35.37 \%$ ). The percentage of people with an insincerity score of 4 to 9 points in patients with mild eczema tends $(p=0.075)$ to higher values compared to healthy subjects $(87.50 \%$ and $64.63 \%$, respectively).

Values from 4 to 9 points on this scale indicate some demonstrative behavior, the desire to seem better in the eyes of others, to express only socially acceptable opinion. On the other hand, psychological research shows that in our country over the past decade, the degree of regulatory support for lies has increased sharply. Today, lies and deception are increasingly perceived by people as normal and natural phenomena, and honesty and truthfulness are not among the important moral qualities of the individual. According to research, $25 \%$ believe that answering insincere questions is quite acceptable and permissible $[3,12]$.

Therefore, it becomes quite clear why the rate of neuroticism, personal and situational anxiety were lower in patients with different forms and course of eczema compared with the control group. And the percentage of patients with various forms and severity of eczema is higher due to subjects with low (all groups of patients) and potentially low levels of neuroticism (true eczema of mild course), low situational (true eczema of mild eczema and microbial eczema of severe course) and personal (severe course of truth eczema) anxiety, and lover - due to patients with potentially high levels of neuroticism (severe course of truth eczema), moderate (severe microbial eczema) and high (severe course of truth eczema) levels of situational anxiety and high levels of anxiety. true eczema of mild course) compared with healthy individuals.

According to Eysenck himself, it is necessary to use psychological tests in combination with the natural sciences, which operate with clear quantitative indicators obtained through objective research methods, the results of which are independent of the researcher and devoid of subjectivity [4], as was the case with our study of anthropometric and somatotypological parameters in patients with eczema in men [1, 2, 9].

O. Y. Shchelkova (2012) notes that the study of personality structure of patients with different forms and severity of the disease is extremely important because personal characteristics largely determine the features of the pathology and response to treatment, psychosocial functioning, adaptation and quality of life of patients [20].

The percentage of subjects with a low level of neuroticism (concordant) tends $(p=0.050)$ to lower values in patients with true severe eczema compared to true mild eczema $(27.78 \%$ and $62.50 \%$, respectively).

The percentage of people with potentially low levels of neuroticism (potential concordant) in patients with true severe eczema $(p<0.01)$ is significantly higher than in patients with true mild eczema and tends $(p=0.080)$ to higher values compared to patients with microbial eczema of severe course $(55.56 \%, 6.25 \%$ and $20.00 \%$, respectively).

The percentage of people with moderate situational anxiety was significantly $(p<0.05)$ lower in patients with severe microbial eczema compared with patients with true severe eczema and mild microbial eczema (40.00\%, 83.33 $\%$ and $78.57 \%$, respectively). The percentage of people with a high level of situational anxiety in patients with severe microbial eczema tends $(p=0.075)$ to higher values compared with patients with mild microbial eczema (30.00 $\%$ and $0 \%$, respectively).

The percentage of people with a high level of personal anxiety tends $(p=0.063)$ to lower values in patients with true eczema of severe course compared with patients with 
true eczema of mild course (0\% and $18.75 \%$, respectively).

For some time in psychosomatic studies, the priority was a trend aimed at finding psychological predictors of dermatoses, but the results of research are ambiguous [8, 10]. Certain personality traits can really determine the development of skin disease, but this cannot be said unequivocally on the basis of personality studies of patients diagnosed with eczema. Changes in personality structure can manifest as a reaction to the diagnosis as a result of its statement. Therefore, it is incorrect to conclude that the found psychological features of patients are absolute predictors of the disease $[14,17]$.

Thus, the results of the study prove the relevance of taking into account the factor of subjectivity in assessing the psychological characteristics of patients with eczema. It is necessary to analyze them in combination with anthropometric studies, which will allow for effective screening of people prone to the disease and predict its occurrence. Assessment of the psychological characteristics of patients with eczema at the same time with the morphometric properties of their body will help to create systemic portraits of patients of different constitutional types.

\section{References}

[1] Al-Omary Ala'a Osama Ahmad, Dmytrenko S. V., Chaika V. H., Isakova N. M., \& Gunas I. V. (2021). Skinfold thickness in men with various forms of eczema. World of Medicine and Biology 3(77), 11-15. doi: 10.26724/2079-8334-2021-3-77-11-15

[2] Al-Omary Ala'a Osama Ahmad, Dmytrenko, S. V., Drachuk, O. P., Yasko, V. V., \& Gunas, I. V. (2020). Features of the girth sizes of the body in men with various forms of eczema. Biomedical and Biosocial Anthropology, 39, 51-56. doi 10.31393/bba39-2020-08

[3] Boyarin, L. V., Zavatsky, Yu. A., Mikhailishin, U. B., \& Zhigarenko, І. Е. (2017). Соціально-психологічні особливості ціннісних орієнтацій особистості в аспекті прояву брехливості [Socio-psychological features of the value orientations of the individual in the aspect of the manifestation of falsehood]. Теоретичні і прикладні проблеми психологіï - Theoretical and applied problems of psychology, 2(43), 36-44.

[4] Burlachuk, L. (2021). Психодиагностика: Учебник для вузов. 2-е изд. [Psychodiagnostics: Textbook for universities. 2nd ed.]. Издательский дом "Питер" - Publishing house "Peter".

[5] Cheng, C., Hsu, J., Huang, K., Bai, Y., Su, T., Li, C., ... \& Chen, M. (2015). Risk of developing major depressive disorder and anxiety disorders among adolescents and adults with atopic dermatitis: A nationwide longitudinal study. Journal of affective disorders, 178, 60-65. doi: 10.1016/j.jad.2015.02.025

[6] Coneo, A., Thompson, A., \& Lavda, A. (2017). The influence of optimism, social support and anxiety on aggression in a sample of dermatology patients: an analysis of cross-sectional data. British Journal of Dermatology, 176(5), 1187-1194. doi: 10.1111/bjd.15115

[7] Dalgard, F. J., Gieler, U., Tomas-Aragones, L., Lien, L., Poot, F., Jemec, G. B., ... \& Kupfer, J. (2015). The psychological burden of skin diseases: a cross-sectional multicenter study among dermatological out-patients in 13 European countries. Journal of Investigative Dermatology, 135(4), 984-991. doi: 10.1038/ jid.2014.530

[8] Dimitrov, D., \& Szepietowski, J. C. (2017). Instruments to assess

\section{Conclusions and prospects for further development}

1. Patients with eczema are more characterized by ambiversion, but this characteristic of temperament determines only the characteristics of behavior within the individual response rate and is not a predictor of this dermatosis.

2. The nature of the psychological structure of the personality of patients with eczema reflects the problem of chronic social and mental maladaptation against the background of a long and severe course of the disease. Patients with severe dermatosis have a higher level of neuroticism (true eczema) and situational anxiety (microbial eczema) compared with patients with mild disease course.

3. Patients with microbial eczema (regardless of its severity) have a higher level of situational anxiety compared to patients with true eczema, which requires optimization of approaches to the prevention and treatment of this form of dermatosis.

Further research is planned to assess the severity and features of accentuated personality traits in patients with eczema depending on the form and severity of the course, which will develop a comprehensive treatment to correct the psychological state and assess its effectiveness.

stigmatization in dermatology. Advances in Hygiene \& Experimental Medicine/Postepy Higieny i Medycyny Doswiadczalnej, 71, 901-905. doi: 10.5604/ 01.3001.0010.5607

[9] Dmytrenko, S. V., Ahmad Al-Omary Ala'a Osama, Dzevulska, I. V., Skoruk, R. V., \& Gunas, I. V. (2020). Features of longitudinal and transverse body sizes in men with various forms of eczema. Reports of Morphology, 26(4), 16-21. doi: 10.31393/ morphology-journal-2020-26(4)-03

[10] Kim, S. H., Hur, J., Jang, J. Y., Park, H. S., Hong, C. H., Son, S. J., \& Chang, K. J. (2015). Psychological distress in young adult males with atopic dermatitis: a cross-sectional study. Medicine, 94(23). doi: 10.1097/MD.0000000000000949

[11] Kudryashov, A. F. (1992). Лучшие психологические тесты для профотбора и профориентации [The best psychological tests for professional selection and career guidance]. Петрозаводск: Петроком - Petrozavodsk: Petrokom.

[12] Majorchak, N. М. (2018). Брехливість особистості в соціально-психологічному контексті: монографрія [The deceitfulness of the individual in the socio-psychological context: a monograph]. Львів: Львівський державний університет внутрішніх справ - Lviv: Lviv State University of Internal Affairs.

[13] Malyszczak, K. (2015). Somatization in anxiety disorders. Med. After Diploma, 7, 45-50.

[14] Marshall, C., Taylor, R., \& Bewley, A. (2016). Psychodermatology in Clinical Practice: Main Principles. Acta dermatovenereologica, 96(217), 30-34. doi: 10.2340/00015555-2370

[15] Nutten, S. (2015). Atopic dermatitis: global epidemiology and risk factors. Annals of nutrition and metabolism, 66 (Suppl. 1), 8-16. doi: $10.1159 / 000370220$

[16] Pavlova, O. V. (2007). Основы психодерматологии [Fundamentals of Psychodermatology]. М.: ЛКИ - M.: LKI.

[17] Perusini, J., \& Fanselow, M. (2015). Neurobehavioral perspectives on the distinction between fear and anxiety. Learning \& Memory, 22(9), 417-425. doi: 10.1101/ 
Im.039180.115

[18] Potebnov, A. G. (1972). Нервные болезни кожи [Nervous skin diseases]. М.: Медицина - M.: Medicina.

[19] Schonmann, Y., Mansfield, K. E., Hayes, J. F., Abuabara, K., Roberts, A., Smeeth, L., \& Langan, S. M. (2020). Atopic eczema in adulthood and risk of depression and anxiety: a populationbased cohort study. The Journal of Allergy and Clinical
Immunology: In Practice, 8(1), 248-257. doi: 10.1016/ j.jaip.2019.08.030

[20] Shchelkova, O. Y. (2012). The Main Areas of Research Activities in St. Petersburg School of Medical (Clinical) Psychology. Vestnik of Saint Petersburg University. Series 16. Psychology. Education, 1, 53-90.

\section{ОСОБЛИВОСТІ ПРОВІДНИХ ТИПОЛОГІЧНИХ ХАРАКТЕРИСТИК ТЕМПЕРАМЕНТУ ТА ПСИХОДИНАМІЧНИХ ОСОБЛИВОСТЕЙ} ОСОБИСТОСТІ У ЧОЛОВІКІВ ХВОРИХ НА РІЗНІ ФОРМИ ЕКЗЕМИ

Аль-Омарі Ала'а Осама Ахмад, Степаненко Р. Л., Матешук-Вацеба Л. Р., Кізіна І. Є., Рекун Т О.

Анотація. Проблема причинно-наслідкових зв'язків у формуванні екземи з точки зору психосоматичного співвідношення наразі залишається актуальною і практично не висвітленою. Застосування комплексного принципу дослідження зумовлює багатогранну оцінку психологічного стану особистості пацієнтів із екземою та можливості його оптимальної корекції. Мета дослідження - вивчити відмінності показників провідних типологічних характеристик темпераменту та психодинамічних особливостей особистості між здоровими та/або хворими на екзему в залежності від тяжкості перебігу дерматозу. Чоловікам віком від 22 до 35 років, з діагнозом істинної та мікробної екземи, проведено оцінку провідних типологічних характеристик темпераменту за опитувальником Айзенка та психодинамічних особливостей особистості за опитувальником Спілбергера-Ханіна. В якості контролю з банку даних науково-дослідного центру Вінницького національного медичного університету ім. М. І. Пирогова були відібрані показники рівня суб'єктивного контролю 82 практично здорових чоловіків аналогічної вікової групи. Статистичну обробку результатів проведено в ліцензійному пакеті "Statistica 5.5" із використанням непараметричних методів оцінки. У цілому встановлено, що серед хворих на екзему 5,6 \% є інтровертами, потенційними інтровертами - 12,3 \%, амбівертами - 44,6 \%, потенційними екстравертами - 29 \% і екстравертами - 8,5 \%. Порівняно із здоровими особами, відсоткова частка хворих з різними фрормами та тяжкістю перебігу екземи більша за рахунок досліджуваних із низьким (усі групи пацієнтів) і потенційно низьким рівнем нейротизму (істинна екзема легкого перебігу), низьким рівнем ситуаційної (істинна екзема легкого перебігу та мікробна екзема тяжкого перебігу) і особистісної (істинна екзема тяжкого перебігу) тривожності, і менша - за рахунок пацієнтів з потенційно високим рівнем нейротизму (істинна екзема тяжкого перебігу), помірним (мікробна екзема тяжкого перебігу) і високим (істинна екзема легкого перебігу) рівнем ситуативної тривожності та високим рівнем особистісної тривожності (істинна екзема легкого перебігу). Пацієнти з тяжким перебігом хвороби характеризуються вищим рівнем нейротизму (істинна екзема) і вищим рівнем особистісної тривожності (мікробна екзема) порівняно з пацієнтами із легким перебігом захворювання. У пацієнтів $з$ мікробною екземою тяжкого перебігу відмічається вищий рівень ситуативної тривожності порівняно з пацієнтами 3 істинною екземою аналогічної тяжкості перебігу. Отже, психодіагностика, яка побудована виключно на самоописі пацієнтами своєї поведінки, емоційного-вольового стану, призводить до несистемності, суб'єктивності, малоінформативності результатів дослідження та не розкриває ні динаміку розвитку захворювання, ні особливості лікування.

Ключові слова: екзема, психологічний тест, тривожність, екстраверсія, інтроверсія, нейротизм. 